\title{
Nationalism, Territoriality and National Territorial Belonging
}

\author{
John Etherington \\ Universitat Autònoma de Barcelona \\ Departament de Ciència Política i Dret Públic \\ john.etherington@uab.es
}

Received: 15-05-2006

Accepted: 01-07-2009

\begin{abstract}
Most studies of nationalism are based on an understanding of the nation as a cultural collectivity that can be located in historical terms in the passage from the pre-modern to the modern era. Rather less attention is paid to spatial considerations. In this light, the paper argues that we cannot fully understand nationalism and its relationship to the nation unless we take into account territory. Firstly, nationalists must make claims over territory, since when they seek some form of self-government for the nation, such political power is premised on the possession of territory. At the same time, such claims and control over territory are justified by fusing nation and territory so that nation and territory come to be seen to belong to each other. The paper challenges the idea of national territorial control based on national territorial belonging from both a theoretical and an empirical perspective, before going on to explore some of the consequences of such a territorial understanding of nationalism, namely that the nation is a category based on spatial separation and thus all nationalist movements must conceive of the nation, at least partially, in exclusive, noncivic terms.
\end{abstract}

Key words. nationalism, nation, national identity, territory, territoriality, national territorial belonging.

\section{Resum. Nacionalismo, territorialidad y pertenencia nacional territorial}

La mayoría de los estudios sobre el nacionalismo entiende la nación como una colectividad cultural que se puede situar en términos históricos en la transición de la época premoderna a la moderna. Se ha prestado menos atención a consideraciones de espacio. En este contexto, este artículo propone que no podemos comprender totalmente tanto el nacionalismo como su relación con la nación, sin tener en cuenta la cuestión del territorio. En primer lugar, los nacionalistas deben hacer reivindicaciones sobre territorio ya que el tipo de poder político que reivindican en nombre de la nación — alguna forma de autogobierno- depende de la posesión de territorio. Al mismo tiempo, se justifica las reivindicaciones sobre el territorio al fusionar nación y territorio de tal manera que parece que uno pertenece al otro y vice versa. Este artículo cuestiona, desde un punto de vista tanto empírico como teórico, la idea de que el control territorial en nombre de la nación se pueda considerar como el corolario natural de la proposición de que nación y territorio pertenecen el uno al otro. Finalmente, el artículo analiza algunas de las consecuencias que puede tener esta manera de comprender el nacionalismo, y en concreto que la nación es una categoría de análisis basa- 
do en la separación espacial y, por tanto, todos los movimientos nacionalistas están obligados a concebir la nación, al menos en parte, en términos exclusivos y no-cívicos.

Palabras clave: nacionalismo, nación, identidad nacional, territorio, territorialidad, pertenencia nacional territorial.

\begin{aligned} & \multicolumn{2}{c}{ Sumary } \\ & Introduction Consequences for Our Understanding of \\ & Nationalism and Territory and Place Nationalism \\ & The Construction of National Territorial Conclusions \\ & Belonging References \end{aligned}

\section{Introduction}

In the vast majority of accounts dealing with the nation and nationalism, nations are perceived as a group of individuals whose members share a set of features, such as a common history, culture, language, religion or even race, that distinguishes them from other nations. Whilst nationalists themselves and primordialist accounts see the nation as an organic entity that expresses itself politically in the form of nationalism, the majority of scholars invert the relationship and talk of how the nation is a modern 'creation', 'invention' or 'imagination' of nationalism. Consequently, attention focuses on the conditions that make nationalism possible, attractive and, in some cases, unavoidable. Ernest Gellner (1964, 1983), for example, centres on the process of industrialisation, Benedict Anderson (1983) on print capitalism and the Enlightenment, while Tom Nairn $(1977,1997)$ looks to uneven capital development as the driving force behind the emergence of nationalism over the past two centuries or so.

However, while any explanation of the nation must take into account or be premised on the common bonds that bind individuals together to form the nation, if our attention solely focuses on this aspect of the nation, then we fail to understand another key aspect of how nationalism constructs the nation. This aspect is most apparent when we talk about, for example, how 'Britain goes to the polls', or how 'Spain faces difficult decisions', or even how 'Catalan is the language of Catalonia. Of course, it would be absurd to think that Britain, Spain and Catalonia here refer to the geographical territories, but then why not talk of Britons, Spaniards and Catalans? Somehow we understand that when we talk of Britain, Spain, Catalonia etc., we are referring not just to a given territory, but rather to some kind of fusion between the people - the nation - and the territory that they occupy or seek to occupy. Far from being an idle, merely semantic preoccupation, the relationship between nation and territory is at the heart of nationalism and has had, and continues to have important political consequences, as the ethnic cleansing of the former territories of Yugoslavia forcefully reminds us. 
In this paper, I wish to develop the idea that we cannot understand nationalism without territory. At one level, the political power that nationalists seek to exercise in the name of the nation is undeniably territorial: state sovereignty or even some form of political autonomy ultimately depends on the possession of territory. But we must go further. When nationalists exercise or seek to exercise control over a given territory in the name of the nation, this is justified by claims that the nation somehow belongs to the territory and that the territory somehow belongs to the nation, and thus it appears 'normal' for nationalists to control it. This mutual belonging, as a means of legitimising nationalist control of territory, can be referred to as national territorial belonging.

Having analysed why territory is so important to nationalism, the paper goes on to deconstruct the relationship between nationalism, the nation and territory. In order to do so it first presents theoretical arguments that challenge the premises underlying the nationalist interpretation of territory and its relation to the nation. Secondly, the paper offers an empirical analysis of the very deliberate process through which nationalism binds nation and territory, a process that has been obviated by the majority of studies that instead have centred almost exclusively on the temporal dimension of national construction. Finally, I shall explore some of the most important consequences of such a territorial understanding of nationalism, and in particular the idea that traditional nonterritorial classifications of nationalisms are inadequate since they are unable to deal with the complex interrelationship between different elements involved in the national construction of identity.

\section{Nationalism and Territory and Place}

From the initial premise that the nation exists, the most politically relevant claim that nationalists make on behalf of the nation is that the latter must rule itself in one way or another. In modern times, national self-government involves either state sovereignty or some form of political autonomy, both of which are premised on the possession of territory, defined as bounded space (Sack, 1986). While objections may be raised as to the extent to which state territoriality has been the norm in practice (see, for example Krasner, 1995), it has undoubtedly been the objective or guiding principle of nationalism: in the words of Gellner, nationalism is a «theory of political legitimacy, which requires that ethnic boundaries should not cut across political ones» (Gellner, 1983: 1). In this respect, once we have accepted that nationalists must make claims over a given territory, the question arises as to how do nationalists justify their claims to territory. Underlying all such claims is the idea of mutual belonging between nation and territory, that is, on the one hand, the nation is said to possesses a unique set of characteristics (for example, cultural, historical and even racial) due to the close contact with a particular national homeland that effectively becomes the cultural container for the nation (Taylor, 1999). On the other hand, the national territory or homeland cannot be understood outside of its 
relationship with the nation, since its defining characteristics are bound it with the nation itself. As Jan Penrose notes, "[f]or Herder, his intellectual descendants and virtually all nationalists, territory is inseparable from the people and the nation is the product of this immutable bonding». (Penrose, 2002: 286).

So powerful has the nationalist paradigm become that we take for granted the nationalist proposition that nations belong to a given territory and vice versa, and thus it appears only 'natural' and 'normal' for nationalists to exercise control of such a territory in the name of the nation. However, as with the existence of the nation itself, little agreement exists among scholars concerning whether or not the nation can be said to belong 'naturally' to its homeland, and vice-versa. Supporting nationalists' claims, Steven Grosby has found examples in Antiquity of peoples drawing their collective identity from territories with fixed borders that were relatively homogeneous in sociological terms. This is explained from a primordial perspective, which is not to say that feelings of attachment to a territory constitute a 'racial or genetic predisposition', but rather they are primordial because people attribute certain life-giving qualities to their attachment to the land (1995: 144). Grosby himself is unsure as to whether this implies the existence of nations, although such findings «should, nevertheless, be sufficient enough to require a more nuanced understanding not only of certain collectivities of antiquity and their respective territories, but modern nationality as well» (1997: 1$)$.

On the other hand, several authors question the primordiality of territorial attachment and stress the modernity of its construction. In this respect, for Michael Billig (1995) national territorial belonging is a distinctly modern phenomenon, since it is only with modernity that 'national' citizens are able to 'imagine' the entire extension of the national homeland and to consider it to be 'theirs'. This is not to deny that in previous historical periods individuals and groups did not feel «a deep sense of attachment» to the land, but rather this attachment was spatially reduced to «their immediate place of living» such as valleys, uplands or lowlands. The «imagining of an overall 'country', in which lived-in localities are united within a wider homeland, does not seem to have been typical in pre-modern Europe» (Billig, 1995: 74).

Second here, even if national territorial belonging could be considered to be a naturally-occurring phenomenon, it is far from 'natural' that territorial belonging should necessarily imply territorial control, as nationalists themselves claim. Such a proposition is premised on the idea that the nation somehow displays a collective, in-born territorial instinct. Yet as Sack (1986) so powerfully argues, such a 'territorial instinct' is not a socio-biologically determined impulse, but rather it is a strategy that can be and, more importantly, has been switched on and off at different points in time and space ${ }^{1}$. Modern state territoriality is a particularly good example of the contingent nature of territoriality, since the kind of control that the modern state came to exercise

1. For a review of competing theories of human territoriality, see Storey (2001). 
over territory was very much an historical novelty. It was only with the advent of the modern age that the state became the

sole political authority with exclusive possession of a defined territory. The state became the dominant form of government, accepting no other agency as rival. The Middle Ages had known no such singular relationship between authority and territory. (Hirst and Thompson, 1996: 171).

The third theoretical objection to the nationalist proposition regarding nation and territory relates to national territory as place, a key concept in geographical analysis. While differing theories exist about the nature of place per se, there does appear to be general agreement among geographers that any specific form of place is socially constructed, and in this respect scholars such as Allan Pred (1984) prefer to see place as a historically contingent process that influences and is influenced by the intersection of structures and individual and institutional practice. Thus, rather than 'being', place should be seen as a constant process of 'becoming'. If we apply this theory to national territory, as Anssi Paasi has done, then territorial units such as national territory are seen as «historical products — not merely in their physical materiality but also in their socio-cultural meanings. Hence territories are not eternal units but, as manifestations of various institutional practices, emerge, exist for some time and disappear» (Paasi, 1996: 3).

\section{The Construction of National Territorial Belonging}

However we understand the territorial nation, it is, I believe, undeniable that nationalist movements over recent centuries have gone to great lengths to stress the unbreakable bond of mutual belonging between nation and homeland. Colin H. Williams and Anthony D. Smith (1983) refer to the process through which national territorial belonging is promoted as the 'national construction of social space', that is a "conscious shaping of perceived reality so that, inter alia, the nation is anchored to a special kind of place, the national territory" (Williams and Smith, 1983: 504). Along similar lines, Paasi introduces the idea of 'national territorial socialisation', which may be understood as the means by which «historically contingent forms of territorial identities, symbols and ideologies are instilled into the social and individual consciousness" (Paasi, 1996: 55). Whichever term we use, both refer to the process whereby nationalists consciously promote the idea within their respective societies that nation and territory are so closely linked as to become almost indistinguishable.

But how does the nation come to be defined in territorial terms? I wish to argue that the nation and territory can be seen as being linked in two major ways. On the one hand, physical features of the land are directly incorporated into national identity, while on the other, at a more symbolic level, nationalist interpretation of the land leads to the fusion of territory and other elements of national identity such as culture, language, common myths and history. Having analysed both aspects of the construction of national territorial belong- 
ing, this section ends with a brief analysis of the instruments that nationalists have traditionally used to promote this dual identification.

\section{Physical elements of national territorial belonging}

Many nationalist movements stress the intimate relationship between nation and the physical characteristics of the land, such as climate, geographical or geo-strategic position, shape and so forth, that are said to affect the character of the people. This can be seen in a number of cases, such as Irish nationalism for which the West of Ireland became the symbol of the whole of Ireland in the late nineteenth century:

Because of what nationalist writers saw as the closeness of the people of the West to the wild landscape, Westerners came to embody all the virtues of Irishness. They were steadfast, dignified and strong, their relationship to the land a source of stability and calm determination (Rose, 1995: 91).

In the case of Spain, Castilians, perched upon their 3,000 feet-high plateau, sun-baked in summer, frozen in winter, isolated from Europe, are said to be of a dry temperament, inward-looking and unreceptive to outside influences. In contrast, Catalonia, with its mountains and coastline, its benign Mediterranean climate, its coastal location and strategic position as 'terra de pas', 'land of passing through', is said to have forged a more open, innovative character of its people, more receptive to outside influences, ideas, people and goods (Vicens Vives, 1962). For Basque Country, on the other hand,

mountain fastness safeguards Basque purity from degenerate Castile, buttressing Basque egalitarian faith against the cosmopolitan nomads - bastardized Celts, decadent Latins, corrupted Moors - of the rest of Spain. (Lowenthal, 1994: 17).

In the 'New World', the 'virgin' character of the land has figured largely in the construction of national identity. In the case of the United States, for example, the vast wilderness of the North American landmass, in contrast to cramped, decadent Europe is said to have left an indelible mark on national identity. In the words of Ronald Reagan:

I have always believed that this land was placed here between the two great oceans by some divine plan. It was placed here to be found by a special kind of people - people who had a special love of freedom and who had the courage to uproot themselves and leave hearth and homeland and come to what in the beginning was the most underdeveloped wilderness possible (quoted in Cresswell, 2004: 72).

In the case of Canadian nationalism, on gaining internal political autonomy from the British government in 1867, the new 'national' Canadian 
government soon faced the difficult task of constructing a national identity for the colonisers. In the absence of a historically-based cultural identity (the indigenous cultures obviously did not count), the government soon became aware of the important role that nature could play in the newly-emerging national identity (Lasserre, 1993). As such it was the vast, cold, desolate wilderness of the North that emerged as a key scenario for the development of Canadian national identity (Lasserre, 1993: 56), whose climate «furthered 'progress', 'democratic spirit', and a 'high and powerful form of civilization'» (Osborne, 1988: 171).

The geo-strategic position of the national homeland is also an important feature of nationalist discourse. Insularity is said to set England apart from Continental Europe, justifying Euroscepticism and the special relationship with the United States, due to England's and Britain's - for most English nationalists the difference is redundant - position as a 'bridge' between the two continents (Lowenthal, 1994).

\section{Symbolic elements of national territorial belonging}

At a more symbolic level, nationalism interprets national territory in such a way as to fuse the national homeland with other elements of national identity such as founding myths, common history and a shared culture, and thus territory becomes inextricably linked with the other core claims of nationalism that were outlined above. In terms of claiming a glorious, distant past for the nation,

associations with the past are central to nationalism's territoriality, for territory is the receptacle of the past in the present. The nation's unique history is embodied in the nation's unique piece of territory —its 'homeland' [...] The time has passed but the space is still there. (Anderson, 1988: 24).

Within this spatial context, monasteries, fields and even trees become sites of national importance; where battles took place, ancient monarchs were crowned, or even where God revealed himself to a chosen people. Thus,

quite plain places like the Rútli, Runnymede, Thingvellir, or Forge Valley become national sites and even architecturally impressive ruins and cities like Delphi, Jerusalem, Pagan and Kyoto are filled with holy memories and charged with collective emotions that far surpass their actual role in history (Williams and Smith, 1983: 509).

For those national identities that contain an element of language, the aim of nationalists is to embed the language in the national territory and demonstrate that it is part of the ancient legacy that the homeland has given to past and present generations. In the case of Welsh nationalism, Williams analyses the important role that the relationship between land, language and people played for leading nationalists such as JR Jones, for whom «centuries of con- 
tinuous occupation confirm the land as the vessel safeguarding and nurturing all cultural traditions» (Williams, 1988: 214).

In this respect, a circular relationship is established between nation, language and homeland whereby

in this marriage and, as its foundations ... we see People, as it were, taking hold of their land and partnering it into the texture of their lives through the intercession of language. They would, as it were, see and handle and love the earth through the mirror of their language. (Jones quoted in Williams, 1988: 216).

A similar relationship was established by Catalan nationalists in the $19^{\text {th }}$-century. In general, great emphasis has traditionally been placed on the language as the prime element of Catalan national identity, with special attention paid to the $19^{\text {th }}$-century literary and linguistic revival, the Renaixença, which for many nationalists was vital not only to the transformation of the Catalan language into a modern literary language of prestige, but also as the most important element of national identity. However, while undoubtedly true, such versions of the Renaixença fail to take into account the process whereby the Catalan language not only became the national language of the Catalan people, but, more importantly, became Catalonia's 'own language' (Fradera, 1992; and Pi de Cabanyes, 1984). This was effectively achieved by promoting the vision that the true essence of the Catalan nation was to be found in the countryside, whose inhabitants were (and are) considered somehow closer to the homeland. As the writers of the Renaixença paid increasing attention to rural Catalonia, its history and cultural and linguistic heritage, so the idea was extended that the Catalan homeland is

'the piece of land that Nature has placed under the same sky and next to the same sea, that makes its sons speak the same language, that makes them live with the same customs and makes them work with the same energy'. There are Catalans, thus, because there is Catalonia, because there is a Catalan land; not vice-versa. (Bonaventura Riera, quoted in Marfany,1995: 202).

\section{The instruments to promote national territorial belonging}

In consonance with the desire to locate the emergence of the nation as a politically relevant category in the transition to modernity, a great deal of scholarly attention has been paid to the important role that archaeologists, anthropologists, historians and so forth have played in 'creating' a glorious past for the nation. Yet less has been made of the spatial pretensions of nationalists: how various instruments have been used to legitimate nationalists' claims over a given territory by fusing the nation in question with such a territory.

In this respect, one of the most important tools for nationalists has been the academic discipline of geography, its teaching in schools, and related prac- 
tices such as mapping. Like many other academic disciplines of the $19^{\text {th }}$ century, geography was very much related to the practical interests of the state (Agnew, 1987), in that the knowledge it provided was a key means of enhancing state control over territory, both 'national' and imperial. However, there is a strong case to be made for seeing the disciplines of geography as a means of encouraging the nation to identify with the national homeland. In this light, geography can be conceived as a means of producing and reproducing national territory, distinguishing it from others, while at the same time subordinating when not ignoring regional geographies within the nation-state framework (Hooson, 1994). Thus geographers played an important role in defining and giving «flesh to the emerging national identity of their country and its place in the world" (Hooson, 1994: 6). This was especially the case of the subject of geography introduced into all school curricula when compulsory schooling was established in late $19^{\text {th }}$-century Europe and beyond. Through the use of atlases, the future citizen had to learn to link an abstract idea (the nation) with a concrete and tangible reality, that is, the physical and spatial setting of the nation (Hooson, 1994: 7. See also Nogué i Font, 1991; and Johnston et al., 1988).

Thus schooling and the general production of maps were soon recognised as powerful weapons by nationalists, in that the former ensure that "people identify with a territory and that they do so as spontaneously as possible, [since] even the most illiterate citizen is capable of interpreting the binomial of map (mapped homeland) equals nation" (Nogué i Font, 1991: 75). In some cases, national territories soon took on recognisable shapes: France became known as the 'Hexagon' and Spain as the 'Bull's skin'.

Hiking is another spatial activity or practice that has played a key role in the spatial construction of the nation. Coinciding with the processes of urbanisation and industrialisation, and with the consequent desire of many sectors of society to temporarily escape towns and cities, hiking came to be seen by a range of nationalist movements as a means of familiarising individuals with the 'national' territory, that they were consequently expected to come to identify with. Scott Moranda talks of how, in Germany, «hiking brought Germans to the forests - a key component of a national symbolic landscape» (Moranda, 2000: 1), while «youth groups aligned with cultural nationalism would understand their activities as an attempt to reinvigorate the nation through nature excursions» (Moranda, 2000: 1). Hiking clubs have also played a key role in the construction of national identity, this time with the mountains at the heart. All four corners of the homeland are explored, flags are placed at the summits of its highest peaks, maps are drawn, places are named, guide books are written, as are poems: to know the homeland is to love it; to love the homeland is to love the nation; to love the nation is to love the homeland. The origins of the hiking movement in Catalonia are very much related to the Renaixença, in that many of the writers of Renaixença were compelled to "establish an inventory of the country» (Casassas i Simó, 1977: 16). Indeed, 
[i]f the Renaixença had not had hiking, which with its scientific nature took it beyond the mere literary field and imbued it with a positive feeling for the land, it would have been reduced to a simple and ephemeral poetic expression [and thus] hiking opened up to the Catalans the desire to know and study Catalonia's own territory and thus a true culture of autochthonous feeling would emerge. (Iglésies, 1964: 24).

Elsewhere, landscape imagery has been an important part of the construction of national identity. In his analysis, Frédéric Lasserre (1993) not only outlines why landscape was important for national identity in Canada, but also discusses the specific measures taken by the government in this respect. Looking at the current success of landscape photography in Canada, Lasserre claims that such success has its origins in the work of a group of landscape painters of the early twentieth century, the Group of Seven, who were well known not only for the artistic quality of their painting, but also for their «structured representation of territory and the nation» (Lassere, 1993: 51). Thus, when the Governor General founded the Royal Academy of Canadian Arts, its first president was the leading landscape painter, O'Brien, who soon set about commissioning a great number of new artists to paint the country, its landscapes and its vastness, so that the emerging Canadian nation might be able to comprehend and come into contact with, albeit at an abstract level, the national homeland. Osborne, quoting the catalogue of one of the collective exhibition of the Group of Seven, talks of the way in which they sought to offer "real 'Art' that 'sincerely interprets the spirit of a nation's growth', one of real value to the country" (Osborne, 1988: 169). One of the members of the group, Lawren Harris, described the 'Great North' as «Virgin», full of «living whiteness», «loneliness» and replenishment, all of which provided a

source of spiritual flow that will ever shed clarity into the growing race of America, and we Canadians being closest to this source seem destined to produce art somewhere different from our southern fellows - an art more spacious, of a greater living quiet, perhaps of a more certain conviction of eternal values. We were not placed between the Southern teeming of men and the ample replenishing North for nothing (Harris, quoted in Osborne, 1988: 172).

Landscape images are also a particular feature of national anthems and popular patriotic songs such as those sung by the soldiers as they went off to war. The national anthems of many countries such as Chile, Austria, Bulgaria, Denmark, Mexico and the newly-independent Croatia - to name just someall make explicit reference to the national homeland (Storey 2001). Not far removed from songs and anthems, is the work of poets and writers, who for Billig represent «a familiar figure in the early stages of movements to establish new nations» since the "mystic bond between people and place is a much repeated theme in their writings» (Billig, 1995: 77). In the case of Catalan nationalism, the work of immensely important poets for the nationalist cause, such as Joan Maragall and Jacint Verdaguer, is full of explicit references to the 
Catalan homeland, a contribution which has guaranteed their place in the pantheon of Catalan writers.

Overall, in this section I have attempted to deconstruct the way in which nationalists come to (con)fuse nation and national territory. By doing so, it becomes clear that there are both theoretical and empirical reasons to believe that nationalism is not only concerned with the task of situating the nation in time, but it must also situate the nation in space. In the final part of this paper, I wish to explore in more detail some of the consequences that the territorial approach to nationalism developed here has for our understanding of nationalism and the way in which it constructs the nation.

\section{Consequences for Our Understanding of Nationalism}

The first area of interest here refers to the relationship that nationalism establishes between territory and other elements of national identity. The accounts of the nation that do recognise territory as a fundamental element of national identity, nevertheless place it on a par with other elements such as a common language, traditions, culture and so forth. However, we are now in a position to understand the relationship between these elements in a different way, since nationalism must locate the nation spatially and does so by binding nation and homeland. Consequently, common language, history and so forth become mediating elements in the relationship between nation and territory. This can be represented graphically (Figure 1):

If, as nationalists claim, the national homeland is the receptacle of cultural, historical, religious and even racial features that make a particular nation special, then a given individual is considered part of the nation precisely

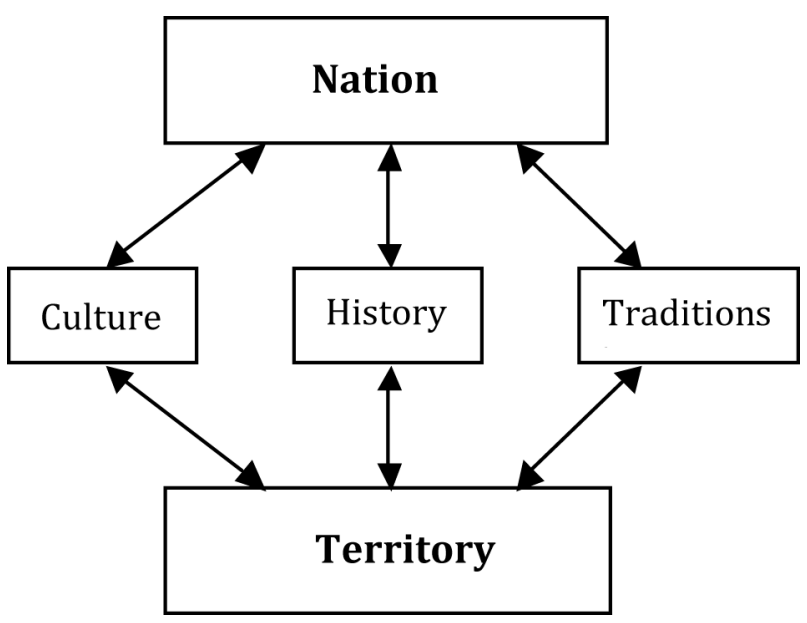

Figure 1. Mediating elements in the relationship nation-territory 
because he or she possesses, takes on, or practices the elements of national identity of which the national homeland is the repository. This is effectively what Jordi Pujol, a contemporary Catalan nationalist leader, means when he says that

language is a decisive factor in the integration of immigrants in Catalonia. It is the most definitive. A man [sic] who speaks Catalan and who speaks Catalan with his children, is already Catalan through and through ${ }^{2}$. The language is [...] the surest and most common way to demonstrate our adhesion - more or less conscious, but real— and our fidelity to Catalonia. (Pujol, 1976: 83).

As such, for nationalists, one belongs to the national territory and thus to the nation by demonstrating adherence to cultural practices that nationalists believe that the national homeland possesses above and beyond the changing patters of occupation by people of different ethnic, cultural and linguistic origins.

The second point I would like to make here is closely related to the first, and concerns the question of whether we can devise a system to classify individual nationalisms according to the relationship established between nation and territory. In the contemporary vocabulary of 'we' and 'the other', both concepts come to be spatially defined, since the national 'we' cannot be understood outside of the spatial context of 'here' — the homeland —, while the same can be said of 'the other' who belongs 'there' — that is, abroad, beyond the boundaries of 'our' homeland (Paasi, 1996). While for many, as we have seen, this proposition is 'common sense', this does not mean that the national 'we' and the national 'here' always coincide. In both practice and theory, this proposition is constantly challenged from variety of sources. First, 'the other' is often 'here' in the national homeland among the national 'we', as in the case of the presence of 'ethnic' minorities. Second, cases arise where state boundaries cut across the national homeland, dividing the nation into more than one territorial setting, causing nationalists to seek to integrate the nation by removing the boundaries between 'here' and 'there'. This may be seen in the case of Irish claims over Northern Ireland, or Basque nationalist claims for the uniting of Basques within the spatial context of Euskal Herria, the 'historic' homeland that is claimed to extend beyond the borders of the Autonomous Community of the Basque Country to Navarre and to parts of France. Third, and more generally, we have already seen how the production and reproduction of national territory is a constant process aimed at maintaining the national scale at the top of the spatial hierarchy, over and above other spatial scales, whether at the local, regional or even supranational level. Particularly under conditions of contemporary globalisation, the emergence of multiple spatial geographies (for

2. The original phrases in Catalan, «català de soca i arrel», literally "Catalan of stump and roots", is an eloquent reflection of the way in which the Catalan language lends itself to the establishment of close ties between the members of the national community and the homeland. 
example, networks of cities, supranational territorial entities such as the EU and so forth) threaten the dominance and fixity of the national scale, and thus challenge the relationship between nation and territory.

Different nationalist movements react in different ways to such challenges, and this reaction has direct political consequences for the treatment of minorities and border disputes, for example. Consequently, in the light of the arguments made so far, the question arises as to whether it is possible to construct categories that recognise the different ways in which nationalist movements react to the challenges to the relationship between nation and territory.

The most commonly-accepted way of classifying nationalisms is the dichotomy made popular by Hans Kohn in the 1940's that opposes ethnic/Eastern/illiberal nationalism and civic/Western/liberal nationalism (Kohn, 1944. See also Greenfeld, 1992; Guibernau, 1999; Ignatieff, 1993; Keating, 1988; and Smith, 1994). In such a scheme, ethnic nationalisms are those that make it difficult for 'the other' to become a member of the nation in question and are thus exclusive, while 'civic' nationalisms are more inclusive, allowing for a greater degree of tolerance towards and integration of the national 'other'. However, the ethnic versus civic dichotomy can be considered problematic, since not only does it lack geographical accuracy — not all Eastern nationalisms are ethnic and vice-versa-, but also it classifies national movements in a once-and-for-all way, ignoring both changes over time and competing elements within (Brown, 1999; and Kuzio, 2002). The underlying problem concerns the very existence of the dichotomy, the idea that a nationalist movement cannot be somehow civic and ethnic at the same time. This, in turn, reflects the absence of a full understanding of the territorial nature of nationalism ${ }^{3}$.

From a territorial point of view, we can identify a number of nationalist movements that have established a purely ethnic basis for national territorial belonging, an extreme example being German Nazism, in that German national belonging was conceived in racial terms, since only Arians, and not Jews, Slavs or Gypsies, belonged on German soil. However, at the other extreme — civic nationalism - to say that no emotional bond exists between nation and territory is rather to miss the point. If, as I have argued, nationalism must bind the nation and homeland, civic nationalism, which conceives of the nation as a community of shared values such as liberty, equality and so forth, is impossible in isolation. It must link the civic national community to the territory claimed by nationalists if the objectives of internal spatial unity and external separation are to be fulfilled. Failure to do so would mean that the civic nation could exist anywhere and, unable to differentiate itself from other nations, it would disappear altogether.

3. Anthony Smith (1991) and Jan Penrose (2002) have both attempted to introduce territorial elements into the civic versus ethnic dichotomy. However, both accounts are to some extent unsatisfactory in that for the former the relationship with the homeland is only important for civic nationalisms, while for the latter the inverse is true. In this respect, both authors ignore the importance of national territorial belonging for all kinds of nationalism. 
An illustration of this argument is the case of nationalism in the United States of America, which has been traditionally put forward as a classic case of civic nationalism. While Eric Kauffman (2000) has recently taken issue, from a non-territorial perspective, with such a proposition, arguing that US nationalism has only recently become civic in recent decades with the influx of migrants from non-European settings, it would appear to be more accurate to say that 'more civic' have coexisted with more ethnic ones throughout the history of the country. In this way, German and Irish immigrants could be incorporated into the national 'we', precisely at a time when the native population was being submitted to what can only be described as genocide for not belonging to the 'land of opportunity' that white Europeans were constructing. Similarly, in the case of late $19^{\text {th }}$-century Canadian nationalism, we have already seen how the land and climate were said to favour 'progress and 'democracy', both of which are values associated with civic nationalism. But this is only half the story, in that, at the same time, the rigours of the climate were also said to exclude the 'negro', the 'Italian organgrinder', and other weaker races (Osborne, 1988: 171). In the case of English nationalism, civic elements are combined with more ethnic elements that are embodied, for example in the long-standing relationship between nation and homeland, with the result that, in certain circumstances, the non-white other is excluded. Gillian Rose points out that the traditional English rural imagery has meant that very few black people have joined organisations such as the National Trust, the Rambler's Association or the Youth Hostel Association. One group concerned with such issues, the Black Environment Network, suggests

that one reason for this may be that the vision of Englishness which rural images of England convey is a white Englishness. The English sense of place discourages black membership or rural organizations because the countryside is not seen as an appropriate location for black people. (Rose, 1995: 116).

Such examples allow us to see that many nationalisms systematically mix elements of civic and ethnic nationalisms, and thus instead of classifying nationalisms according to the civic versus ethnic dichotomy, we might identify different elements that mediate the relationship between nation and territory that are distinct in an analytical sense, but that in practice often come together in a symbiotic way. In order to see this analytical separation better, we can arrange them on a heuristic continuum ranging from more 'exclusive' to more 'inclusive' elements - more ethnic and more civic in the traditional scheme- of the relationship between the nation and the homeland (Figure 2).

At one extreme, we find racial elements which make it impossible for 'the other' of a different race to belong to the homeland and thus to the nation. Very close to race on the continuum we might find a strong religious element in national territorial belonging, whereby in order to belong to the homeland and the nation, the 'other' must convert to the dominant national religion of the homeland. Historically, this has proved most difficult, and has been the 


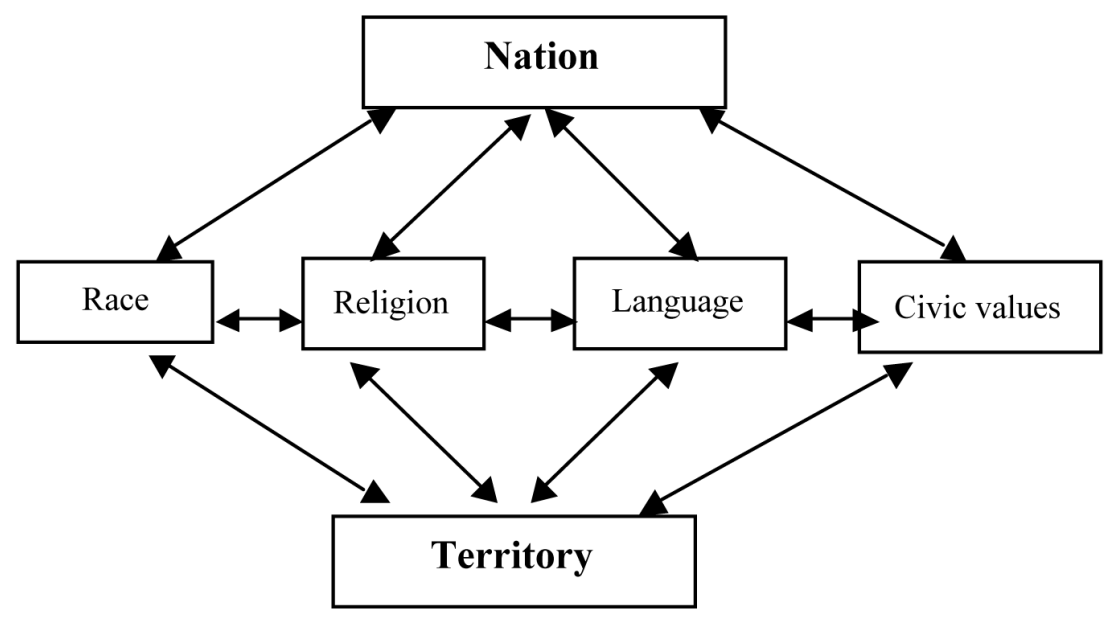

more exclusive $\longrightarrow$ more inclusive

Figure 2. Inclusive and exclusive elements of the relationship nation-territory

source of conflict, for example in Ireland or in the former Yugoslavia and Palestine/Israel, where racial and religious interpretations of national territory often coincide and reinforce each other. Moving further towards more inclusive' elements, we find cultural or linguistic terms of belonging, whereby 'the other' might be said to belong when he or she assumes the cultural legacy of the homeland as his/her own. This is how we might interpret Jordi Pujol's claims quoted above concerning the need for immigrants to speak the Catalan language as a means of showing one's will to belong to the national homeland and consequently to the Catalan nation. Finally, where the relationship between nation and territory is based on values such as 'democracy', 'liberty' and so forth, national belonging is even more open to 'the other', in that by pledging one's loyalty, say, to a constitution that embodies such values, one is implicitly pledging one's allegiance to the national homeland, and thus to the nation.

However, it bears repeating that such elements are not mutually exclusive, and in many cases one cannot understand nationalist movements without an appreciation of simultaneous occurrence of such elements. Nationalism based on exclusively civic elements is impossible since it fails to locate the nation spatially and thus fails to legitimate claims regarding the exclusive exercise of power over bounded space. Thus, where civic elements do exist, they relate in a symbiotic and not mutually-exclusive way to ethnic elements, in contrast to the traditional civic-versus-ethnic dichotomy. We can only understand why this occurs if we understand nationalism as a political doctrine that (con)fuses nation and territory as a means of legitimising political territorial power. 


\section{Conclusions}

In order to conclude, throughout this article I have argued that territory is central to understanding nationalism. When nationalists seek self-government, they are obliged to lay claims to territory since the political power that nationalists seek to exercise is necessarily territorial. Nationalists justify such claims by promoting the idea that nation and territory belong to each other, and consequently it is only 'natural' for nationalists to govern in the name of the nation.

Yet there are good reasons to question the relationship that nationalists promote between nation and territory as a means of legitimising political power: there is nothing 'natural' about national territorial belonging nor about national territorial control. In addition, nationalist movements have spent a great deal of time and effort in promoting national territorial belonging despite claiming that it is a natural occurrence. Once we have established this argument, we may draw several related conclusions about nationalism and the way in which it relates to territory.

On the one hand, the nation emerges as a modern construct in the sense that it is only possible and necessary with the emergence of modern state territoriality, understood as the establishment of centralised control over, inter alia, people and resources by exercising control over territory. In as much as state territory needs to be internally unified and externally differentiated, so too must the population within the territory that is subject to control. It is in this sense that nationalism brings the nation into being as a unique human group belonging to a unique territory or homeland.

On the other hand, the need to root that nation in the homeland means that elements of national identity, such as a shared language, history or culture, can only be understood to the extent to which they mediate the relationship between nation and territory; in other words, such elements may be considered as different means of linking nation and territory. Whilst different nationalist movements link nation and territory in different ways, we must be aware that this relationship is key to all nationalist movements, otherwise the nation in question could exist anywhere and thus nowhere. In this light, purely civic nationalism is impossible in isolation, since the civic construction of the nation must be accompanied by more ethnic elements as a means of establishing a special relationship between nation and territory, if claims to territorial selfgovernment are to be legitimised. Consequently, instead of opposing civic and ethnic elements of the nation, we see how often they come together in a symbiotic way.

At a more general level, this paper has centred on the question of how nationalism constructs the nation in function of the needs of modern state territoriality. However, given that the latter is also a contingent strategy, any general theory of nationalism would ultimately have to explicate modern state territoriality. We could talk at a general level of the reasons for the emergence of the principle of state territoriality in the modern age, but this would not go far enough. In practice, the degree to which the principle of absolute author- 
ity over bounded space that is implied by the term has been respected varies greatly over time and space, and therefore any overall explanation of nationalism would have to be capable of explaining such difference. While the construction of such a theory has not been the objective of the current article, by offering a territorial understanding of nationalism, we are at least in a better position to understand what nationalism is, and how and why it relates to territory.

\section{References}

AgneW, John (1987). Place and Politics: The Geographical Mediation of State and Society. Boston: Allen and Unwin.

ANDERSON, Benedict (1983). Imagined Communities. Reflections on the Origin and Spread of Nationalism. London: Verso.

ANDERSON, James (1988). «Nationalist Ideology and Territory». In: JoHnSTON, Richard. J.; KNIGHT, David and Kofman, Elenor (eds.). Nationalism, SelfDetermination and Political Geography. London: Croom Helm.

BENNER, Erica (2001). «Is there a core national doctrine?». Nations and Nationalism 7(2), 155-174.

BILLIG, Michael (1995). Banal Nationalism. London: Sage.

BROWN, David (1999). «Are there good and bad nationalisms?». Nations and Nationalism 5(2), 281-302.

CASASSAS i Simó, Lluis (1977). «Pròleg». In: VILA, Pau (ed.). La Divisió Territorial de Catalunya. Volum Primer de Selecció d'Escrits de Geografia. Barcelona: Curial.

CRESSWELl, Tim (2004). Place: a short introduction. Oxford: Blackwell.

Fradera, Josep-Maria (1992). Cultura Nacional en una Societat Dividida. Barcelona: Curial.

Gellner, Ernest (1964). Thought and Change. London: Weidenfield and Nicolson. - (1983). Nations and Nationalism. Oxford: Basil Blackwell.

GreenfeldGrosby, Liah (1992). Nationalism: Five Roads to Modernity. Cambridge, MA: Harvard University Press,

GROSBY, Steven (1995) «Territoriality: the transcendental, primordial feature of modern societies». Nations and Nationalism, 1(2), 143-62.

- (1997) «Borders, Territory and Nationality in the Ancient Near East and Armenia». Journal of Economic and Social History of the Orient, 40(1), 1-29.

Guibernau, Montserrat (1999). Nations without States: Political Communities in a Global Age. Cambridge: Polity Press.

Hirst, Paul and ThOMPson, Graham (1996). Globalization in Question. Cambridge: Polity Press.

Hooson, David. (1994) «Introduction». In: Hooson (ed.). Geography and National Identity. Oxford: Basil Blackwell.

IglésIES, Josep (1964). Enciclopèdia de l'Excursionisme, Vol. 1. Barcelona: Rafael Dalmau. IgNATIEFF, Michael (1993). Blood and Belonging: Journeys into the New Nationalism. New York: Farrar, Strauss and Giroux.

Johnston, Richard. J.; Knight, David and Kofman, Elenor (1988) «Nationalism, Self -Determination and the World Political Map: An Introduction». In: JOHNSTON, Knight and Kofman (eds.). Nationalism, Self-Determination and Political Geography. London: Croom Helm. 
Kaufmann, Eric. (2000) «Ethnic or Civic Nation?: Theorizing the American Case». Canadian Review of Studies in Nationalism, XXVII, 133-154.

Keating, Michael (1988). The State and Regional Nationalism. Territorial Politics and the European State. New York: Harvester Wheatsheaf.

KoHN, Hans (1944). The Idea Of Nationalism: A Study in Its Origins and Background. New York: MacMillan.

KRASNER, Steven (1995). «Compromising Westphalia». International Security, 20(3), 115-151.

Kuzio, Taras (2002). «The Myth of the Civic State: a critical survey of Hans Kohn's framework for understanding nationalism». Ethnic and Racial Studies, 25(1), 20-39.

LASSERRE, Frédéric (1993). «Paysage, peinture et nationalisme». Géographie et Cultures, $8,51-70$.

Lowenthal, David (1994). «European and English Landscapes as Symbols». In: Hooson, David (ed.). Geography and National Identity. Oxford: Basil Blackwell.

MARFANY, Joan-Lluis (1995). La Cultura del Catalanisme: El nacionalisme català en els seus inicis. Barcelona: Editorial Empúries.

Moranda, Scott (2000). Maps, Markers and Bodies: Hikers Constructing the Nation in German Forests. On line at: http://www.nationalismproject.org/articles/Moranda/ moranda.html [Consulted: 24th March 2003].

NAIRn, Tom (1977). The Break-up of Britain: Crisis and Neo-Nationalism. London: Verso.

NAIRn, Tom (1997). Faces of Nationalism: Janus Revisited. London: Verso.

Nogué I Font, Joan (1991). Els Nacionalismes i el Territori. Barcelona: El Llamp.

Osborne, Brian S. (1988). "The iconography of nationhood in Canadian art». In: Denis CosGrove and Daniels, Stephen (ed.). The Iconography of Landscape. Essays on the symbolic representation, design and use of past environments. Cambridge: Cambridge University Press.

PAASI, Anssi (1996). Territories, Boundaries and Consciousness. The Changing Geographies of the Finnish-Russian Border. Chichester: John Wiley and Sons.

Penrose, Jan (2002). "Nations, states and homelands: territory and territoriality in nationalist thought». Nations and Nationalism 8(3), 277-297.

PI DE CABANYES, Oriol (1984). Apunts d'Història de la Renaixença. Sant Boi de Llobregat: Edicions del Mall.

Pred, Allan (1984). «Place as Historically Contingent Process: Structuration and the Time-Geography of Becoming Places». Annals of the Association of American Geographers, 74(2), 279-297.

Pujol, Jordi (1976). La Immigació, Problema i Esperança de Catalunya. Barcelona: Editorial Nova Terra.

Rose, Gillian (1995). «Place and identity: a sense of place». In: MASSEY, Doreen and Jess, Pat (eds.). A Place in the World: Places, Cultures and Globalization. Oxford: Open University/Oxford University Press.

SACK, Robert (1986). Human Territoriality: Its theory and history. Cambridge: Cambridge University Press.

Smith, Anthony D. (1983). Theories of Nationalism. London: Duckworth.

- (1991). National Identity. London: Penguin.

- (1994). "The problem of national identity: ancient, medieval and modern?». Ethnic and Racial Studies, 17(3), 375-399.

STOReY, David (2001). Territory: the Claiming of Space. Harlow: Prentice Hall. 
TAYLOR, Peter J. (1999). Modernities. A Geohistorical Interpretation. Cambridge: Polity Press.

Vicens Vives, Jaume (1962) Notícia de Cataluña. Barcelona: Ediciones Destino. Williams, Colin H. (1988) «Minority Nationalist Historiography». In: JOHNSTON, Richard. J.; Knight, David and Kofman, Elenor (eds.). Nationalism, SelfDetermination and Political Geography. London: Croom Helm.

Williams, Colin H. and Smith, Anthony D. (1983). «The National Construction of Social Space». Progress in Human Geography, 7(4), 502-518. 